\title{
Information on occupation of patients with Covid-19: Literature review
}

\author{
(iD) Carlos Dornels Freire de Souza ${ }^{1}$ \\ (iD) Aisla Graciele Galdino dos Santos ${ }^{1}$ \\ (iD) Euclides José Oliveira da Cunha ${ }^{1}$ \\ (iD) Tatiana Farias de Oliveira ${ }^{1}$ \\ (D) Saulo Henrique Salgueiro de Aquino' \\ (iD) Rodrigo da Rosa Mesquita ${ }^{1}$ \\ Luiz Carlos Francelino Silva Junior ${ }^{1}$ \\ (iD) Fernanda Mayara Santos Santana ${ }^{1}$ \\ (iD) Rafaela Campos Alcântara ${ }^{1}$ \\ (D) Gabriel Monteiro Arnozo ${ }^{1}$ \\ (iD) Etvaldo Rodrigues da Silva Filho'
}

Dear Editor,

Covid-19 was recorded for the first time in Wuhan, the capital of the Hubei province, in China, in December 2019. The disease is caused by a new coronavirus (Sars-COV-2) and transmitted by the sharing of aerosols ${ }^{1}$. From its origin until the $21^{\text {st }}$ of April of 2020, the disease had already caused the death of more than 175,000 people worldwide. There had been more than 2.5 million confirmed cases on this date ${ }^{2}$.

The World Health Organization (WHO) declared Covid-19 a pandemic on 11 March $2020^{3}$ and, since then, has been, along with its member countries, seeking mechanisms to control the disease. Since this is a new disease, scientists have been working hard to develop research that allows the decision making by doctors and public managers.
The number of investigations about the profile of patients with Covid-19 grows daily, with the intention of identifying characteristics that are associated with a greater risk of illness and death. Among these characteristics, occupation stands out. Identifying patients' professional profile can bring benefits for the effective control of the pandemic: i. identification of possible locations of contamination, ii. adoption of safety measures in the workplace; and iii. knowledge about the role of occupation in the transmission dynamics of the disease.

A systematic review of the literature was conducted involving scientific articles that describe the epidemiological characteristics of patients hospitalized with Covid-19 worldwide. Articles published in the PubMed, MEDLINE, and Scopus databases 
between 1 January and 24 April 2020 were selected using the following descriptors: Covid-19, Sars-CoV-2, 2019-nCoV, n-VOC, and coronavirus combined with clinical profile, epidemiology. The search was conducted on 24 April 2020.

In the study, trials, cohort studies, cross-sectional studies, clinical cases, and series of cases, both published and in pre-print, were included. The following exclusion criteria were adopted: government epidemiological bulletins, comments, literature reviews, and articles without access to their full content. After the search, three authors, independently, completed the following steps: 1- reading of the title and summary, 2reading of the full article, 3 - collection of data relating to occupation, and database assembly. The analysis was done by two other researchers independently. Then, the differences were analyzed by the investigation team.

Initially, we found 7,489 scientific papers in the databases. Of these, 158 met the inclusion criteria, totaling 100,563 patients from all continents. After reading them in full, only $18^{3-20}$ papers had information on occupation (Figure 1): Brasil (one text; 81 patients), Thailand (one text; 11 patients), USA (one text; 48 patients), and China ( 15 texts; 47,870 patients), totaling 48,010 individuals, homogeneously distributed between sexes ( $51.62 \%$ men and $48.38 \%$ women) (Table 1).

FIGURE 1. PAPER SELECTION FLOWCHART, 2020.

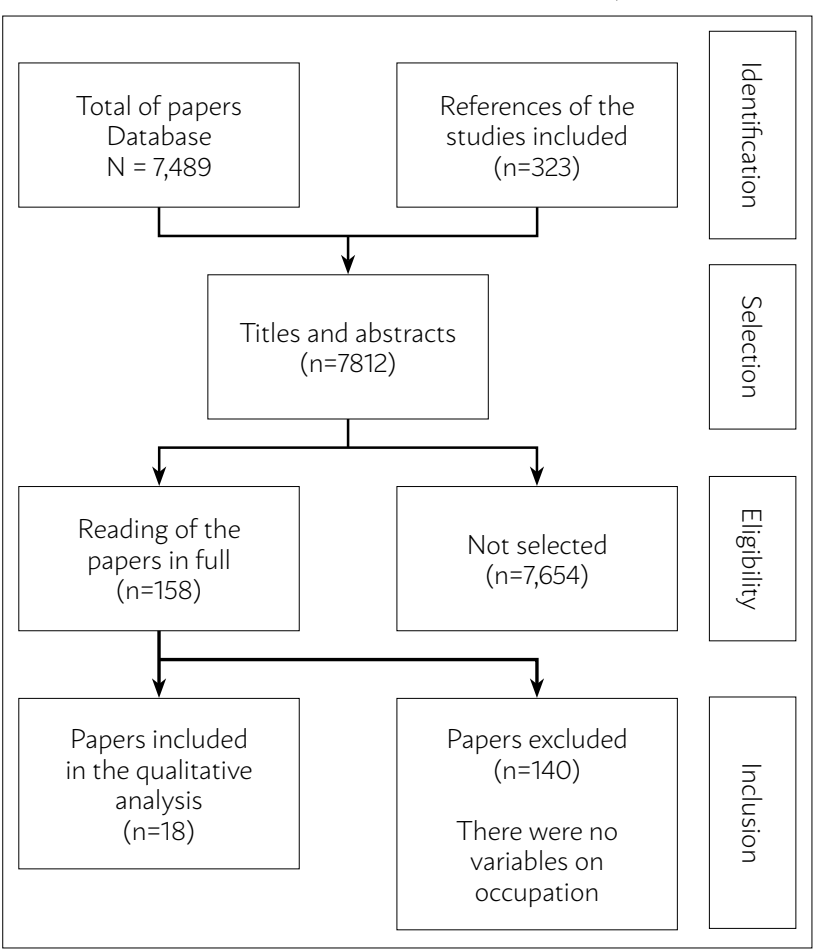

In relation to professional activity, two occupations can be highlighted: $20.76 \%(n=9963)$ of patients were farmers and $19.77 \%(n=9,488)$ retired. Among the other individuals, $7.19 \%(\mathrm{n}=3,453)$ worked in the service industry, $4.34 \%(\mathrm{n}=2,085)$ were health professionals, 0.68\% $(\mathrm{n}=327)$ employees, and 0.61\% $(\mathrm{n}=295)$ self-employed. Four studies $(3,6,9,18)$ defined the other occupancies in the category 'other', corresponding to $43.16 \%(n=20,719)$ of individuals studied. Eight papers ${ }^{3,5,7,10,11,12,12,17}$ characterized the occupation of part of the cases, without information on the others, which were included in the field "not informed" $(n=1,680$; 3.49\%) (Table 1).

The records of health professionals with the disease were observed in 12/18 articles, and four ${ }^{13,14,16,19}$ of them were conducted exclusively on these professionals. In seven others ${ }^{3,5,7,10,11,15,17}$, professions were not investigated, but the text highlighted the number of health professionals with Covid-19. Excluding the studies composed exclusively by health professionals, the frequency of this category varied from 3.5\% to $29.0 \%$ (Table 1).

In outbreaks of infectious diseases, occupation and work environment can play an important role in the dissemination of infection due to a variety of actions that can promote this spread, such as contact with customers, food preparation, and others ${ }^{21}$. Studies on other diseases have already stressed the importance of professional activity in the dynamics of transmission: Danovaro-Holliday et al. ${ }^{22}$, for example, showed that agglomerations and precarious living conditions favored outbreaks of rubella.

Approximately $10 \%$ ( $\mathrm{n}=14.4$ million) of workers in the United States are employed in occupations in which exposure to diseases occurs at least once a week; and $18.4 \%$ ( $n=26.7$ million) workers there are employed in occupations in which exposure to morbidities occurs at least once a month ${ }^{21}$. Given this scenario, it becomes relevant, in studies and research carried out on Covid19 , to identify the professional activities of individuals and their place of work to understand the relationship between occupation and the spread of the disease.

In this review, we observed that of 48,010 individuals, 1,680 were in the category of occupation not informed and 20,719 in the other category, which represents a shortage in specific definitions of occupation in $46,65 \%$ of the population studied. This lack of information, in general, can compromise the reliability of epidemiological information and generate false correlations in the diagnoses of health (23). 
TABLE 1. CHARACTERIZATION OF THE PAPERS INCLUDED IN THE STUDY ( $N=18), 2020$.

\begin{tabular}{|c|c|c|c|c|c|c|c|c|c|c|c|c|}
\hline \multirow[b]{2}{*}{ Paper } & \multirow[b]{2}{*}{$\begin{array}{l}\text { Coun- } \\
\text { try }\end{array}$} & \multirow[b]{2}{*}{$\mathrm{N}$} & \multicolumn{2}{|c|}{ Sex } & \multicolumn{8}{|c|}{ Occupations reported } \\
\hline & & & $\begin{array}{l}\text { Male } \\
(\%)\end{array}$ & $\begin{array}{l}\text { Female } \\
(\%)\end{array}$ & $\begin{array}{l}\text { Agricul- } \\
\text { ture } \\
(\%)\end{array}$ & $\begin{array}{l}\text { Services } \\
(\%)\end{array}$ & $\begin{array}{l}\text { Self-em- } \\
\text { ployed } \\
(\%)\end{array}$ & $\begin{array}{l}\text { Em- } \\
\text { ployed } \\
(\%)\end{array}$ & $\begin{array}{l}\text { Retired } \\
(\%)\end{array}$ & $\begin{array}{l}\text { Health } \\
\text { profession- } \\
\text { als (\%) }\end{array}$ & $\begin{array}{l}\text { Others } \\
(\%)\end{array}$ & $\begin{array}{l}\text { Not in- } \\
\text { formed } \\
(\%)\end{array}$ \\
\hline $\begin{array}{l}\text { Borba et } \\
\text { al. }(3)^{a}\end{array}$ & Brasil & 81 & $\begin{array}{c}61 \\
(75.4 \%) \\
\end{array}$ & $\begin{array}{c}20 \\
(24.7 \%)\end{array}$ & - & - & - & - & - & $\begin{array}{c}5 \\
(6.2 \%)\end{array}$ & - & $\begin{array}{c}76 \\
(93.8 \%)\end{array}$ \\
\hline $\begin{array}{l}\text { Wang et al. } \\
(4)^{b, c}\end{array}$ & China & 26 & $\begin{array}{c}11 \\
(42.3 \%)\end{array}$ & $\begin{array}{c}15 \\
(57.7 \%)\end{array}$ & $\begin{array}{c}2 \\
(7.7 \%)\end{array}$ & - & $\begin{array}{c}1 \\
(3.9 \%)\end{array}$ & $\begin{array}{c}16 \\
(61.5 \%)\end{array}$ & $\begin{array}{c}4 \\
(15.4 \%)\end{array}$ & - & $\begin{array}{c}3 \\
(11.5 \%)\end{array}$ & - \\
\hline Li et al. (5) a & China & 548 & $\begin{array}{c}279 \\
(50.9 \%)\end{array}$ & $\begin{array}{c}269 \\
(49.1 \%)\end{array}$ & - & - & - & - & - & $\begin{array}{c}45 \\
(8.2 \%)\end{array}$ & - & $\begin{array}{c}503 \\
(91.8 \%)\end{array}$ \\
\hline $\begin{array}{l}\text { Shi et al. } \\
(6)^{c}\end{array}$ & China & 487 & $\begin{array}{c}259 \\
(53.2 \%)\end{array}$ & $\begin{array}{c}228 \\
(46.8 \%)\end{array}$ & $\begin{array}{c}140 \\
(28.7 \%)\end{array}$ & - & $\begin{array}{c}219 \\
(45 \%) \\
\end{array}$ & $\begin{array}{c}82 \\
(16.8 \%)\end{array}$ & $\begin{array}{c}38 \\
(7.8 \%) \\
\end{array}$ & - & $\begin{array}{c}8 \\
(1.6 \%)\end{array}$ & - \\
\hline $\begin{array}{l}\text { Wang et al. } \\
(7)^{\mathrm{a}}\end{array}$ & China & 138 & $\begin{array}{c}75 \\
(54.3 \%) \\
\end{array}$ & $\begin{array}{c}63 \\
(45.7 \%)\end{array}$ & - & - & - & - & - & $\begin{array}{c}40 \\
(29.0 \%)\end{array}$ & - & $\begin{array}{c}98 \\
(71 \%) \\
\end{array}$ \\
\hline $\begin{array}{l}\text { Chen et al. } \\
(8)\end{array}$ & China & 99 & $\begin{array}{c}67 \\
(67.7 \%) \\
\end{array}$ & $\begin{array}{c}32 \\
(32.3 \%) \\
\end{array}$ & $\begin{array}{c}2 \\
(2 \%)\end{array}$ & - & $\begin{array}{c}63 \\
(63.6 \%)\end{array}$ & $\begin{array}{c}15 \\
(15.1 \%)\end{array}$ & $\begin{array}{c}19 \\
(19.2 \%)\end{array}$ & - & - & - \\
\hline $\begin{array}{l}\text { CCDCP } \\
(9)^{d}\end{array}$ & China & 44672 & $\begin{array}{c}22,981 \\
(51.44 \%)\end{array}$ & $\begin{array}{c}21,691 \\
(48.55 \%) \\
\end{array}$ & $\begin{array}{c}9,811 \\
(22 \%) \\
\end{array}$ & $\begin{array}{l}3,449 \\
(7.7 \%) \\
\end{array}$ & - & - & $\begin{array}{c}9,193 \\
(20.6 \%)\end{array}$ & $\begin{array}{c}1,716 \\
(3.8 \%)\end{array}$ & $\begin{array}{l}20,503 \\
(45.9 \%)\end{array}$ & - \\
\hline $\begin{array}{l}\text { Lai et al, } \\
\text { 2020. (10)a }\end{array}$ & China & 278 & $\begin{array}{c}172 \\
(61.88 \%)\end{array}$ & $\begin{array}{c}106 \\
(38.12 \%)\end{array}$ & - & - & - & - & - & $\begin{array}{c}40 \\
(14.4 \%)\end{array}$ & - & $\begin{array}{c}238 \\
(85.6 \%)\end{array}$ \\
\hline $\begin{array}{l}\text { Li et al, } \\
\text { 2020. (11)a }\end{array}$ & China & 425 & $\begin{array}{c}240 \\
(56.47 \%)\end{array}$ & $\begin{array}{c}185 \\
(43.53 \%)\end{array}$ & - & - & - & - & - & $\begin{array}{c}15 \\
(3.5 \%)\end{array}$ & - & $\begin{array}{c}410 \\
(96.5 \%) \\
\end{array}$ \\
\hline $\begin{array}{l}\text { An et al. } \\
(12)^{\mathrm{e}}\end{array}$ & China & 25 & $\begin{array}{c}17 \\
(68 \%) \\
\end{array}$ & $\begin{array}{c}8 \\
(32 \%)\end{array}$ & - & - & - & $\begin{array}{c}3 \\
(12 \%)\end{array}$ & - & - & - & $\begin{array}{c}22 \\
(88 \%)\end{array}$ \\
\hline $\begin{array}{l}\text { Wang et al. } \\
\text { (13) }\end{array}$ & China & 80 & $\begin{array}{c}31 \\
(38.75 \%) \\
\end{array}$ & $\begin{array}{c}49 \\
(61.25 \%) \\
\end{array}$ & - & - & - & - & - & $\begin{array}{c}80 \\
(100 \%)\end{array}$ & - & - \\
\hline $\begin{array}{l}\text { Liu et al. } \\
\text { (14) }\end{array}$ & China & 30 & $\begin{array}{c}10 \\
(33.3 \%)\end{array}$ & $\begin{array}{c}20 \\
(66.6 \%)\end{array}$ & - & - & - & - & - & $\begin{array}{c}30 \\
(100 \%)\end{array}$ & - & - \\
\hline $\begin{array}{l}\text { Cao et al. } \\
(15)^{\text {a }}\end{array}$ & China & 102 & $\begin{array}{c}53 \\
(52 \%)\end{array}$ & $\begin{array}{c}49 \\
(48 \%)\end{array}$ & - & - & - & - & - & $\begin{array}{c}24 \\
(23.5 \%)\end{array}$ & - & $\begin{array}{c}78 \\
(76.5 \%)\end{array}$ \\
\hline $\begin{array}{l}\text { Zhan et al. } \\
(16)\end{array}$ & China & 23 & $\begin{array}{c}17 \\
(73.9 \%)\end{array}$ & $\begin{array}{c}6 \\
(26.1 \%)\end{array}$ & - & - & - & - & - & $\begin{array}{c}23 \\
(100.0 \%)\end{array}$ & - & - \\
\hline $\begin{array}{l}\text { Chen et al. } \\
(17)^{a}\end{array}$ & China & 274 & $\begin{array}{c}171 \\
(62.4 \%)\end{array}$ & $\begin{array}{c}103 \\
(37.6 \%)\end{array}$ & - & - & - & - & - & $\begin{array}{c}19 \\
(6.9 \%)\end{array}$ & - & $\begin{array}{c}255 \\
(93.1 \%)\end{array}$ \\
\hline $\begin{array}{l}\text { Zhang et } \\
\text { al. }(18)^{d}\end{array}$ & China & 663 & $\begin{array}{c}321 \\
(48.4 \%) \\
\end{array}$ & $\begin{array}{c}342 \\
(51.6 \%)\end{array}$ & $\begin{array}{c}8 \\
(1.2 \%) \\
\end{array}$ & - & $\begin{array}{c}12 \\
(1.8) \\
\end{array}$ & $\begin{array}{c}211 \\
(31.8) \\
\end{array}$ & $\begin{array}{c}227 \\
(34.2 \%)\end{array}$ & - & $\begin{array}{c}205 \\
(30.9 \%)\end{array}$ & - \\
\hline $\begin{array}{l}\text { Chow et al. } \\
\text { (19) }\end{array}$ & USA & 48 & $\begin{array}{c}11 \\
(22.9 \%)\end{array}$ & $\begin{array}{c}37 \\
(77.1 \%) \\
\end{array}$ & - & - & - & - & - & $\begin{array}{c}48 \\
(100.0 \%) \\
\end{array}$ & - & - \\
\hline $\begin{array}{l}\text { Pongpirul } \\
\text { et al. (20) }\end{array}$ & $\begin{array}{l}\text { Thai- } \\
\text { land }\end{array}$ & 11 & $\begin{array}{c}6 \\
(55 \%) \\
\end{array}$ & $\begin{array}{c}5 \\
(45 \%) \\
\end{array}$ & - & $\begin{array}{c}4 \\
(36.4 \%)\end{array}$ & - & - & $\begin{array}{c}7 \\
(63.6 \%)\end{array}$ & - & - & - \\
\hline Total & - & $\begin{array}{l}48,010 \\
(100.0 \%)\end{array}$ & $\begin{array}{l}24,782 \\
(51.62 \%)\end{array}$ & $\begin{array}{l}23,228 \\
(48.38 \%)\end{array}$ & $\begin{array}{l}9,963 \\
(20.76 \%)\end{array}$ & $\begin{array}{l}3,453 \\
(7.19 \%) \\
\end{array}$ & $\begin{array}{l}295 \\
(0.61 \%)\end{array}$ & $\begin{array}{l}327 \\
(0.68 \%)\end{array}$ & $\begin{array}{l}9488 \\
(19.77 \%)\end{array}$ & $\begin{array}{l}2,085 \\
(4.34 \%)\end{array}$ & $\begin{array}{l}20,719 \\
(43.16 \%)\end{array}$ & \begin{tabular}{|l}
1,680 \\
$(3.49 \%)$
\end{tabular} \\
\hline
\end{tabular}

Legend: a- The study does mention the professions, but highlights the number of health professionals; b- The study highlights that the 'Retail Staff' occupation was the most common, with 11 individuals working in the same supermarket. This occupation was classified as "employed"; c- The work includes the occupation 'Student' reclassified as "other"; d- Occupation classified as "other" was not specified; $\mathbf{e}$ - The study shows that three patients were involved in medical waste cleaning. The 22 classified as not informed are relatives of these patients.

The correct identification of patients' occupational profiles can bring benefits for the effective control of the pandemic, guiding the adoption of effective safety measures in work environments. In the study by Wang et al. ${ }^{4}$, of the 16 retail professionals contaminated by Covid-19, 11 and their relatives worked in the same supermarket. This scenario reinforces the need for rigorous monitoring of occupations and workplaces of patients, which is essential to prevent and/or reduce the spread of the virus in these locations and from them to their families and the community in general.
From the mapping of the professions most vulnerable to contagion, it is possible to develop actions of infection prevention and containment, as shown in the study by Wang et al. ${ }^{13}$, in which health professionals present peculiar clinical and laboratory characteristics, which differ from those of people with other occupations and, therefore, require special attention and targeted biosafety.

According to data from the US Department of Health and Human Services/Centers for Disease Control and Prevention, 19\% $(n=9,282)$ of the confirmed Covid-19 cases in the United States were identified 
in health professionals. These data may be underestimated since the health professional occupation was available only in $16 \%$ of the cases reported throughout the country ${ }^{24}$. In our analysis, 12 studies reported this occupation, making it necessary to ensure control in healthcare environments to reduce transmission. The contamination of these professionals has implications for the health system, both regarding the occupation of hospital beds as well as the reduction of the labor force available.

The papers used in this study present limitations. The diversity of classifications of the occupation variable hinders the identification of a risk profile. Another obstacle is the restriction of geographical area, since out of the 18 studies reviewed, 15 were conducted in the same country (China), which represents a percentage of $99.70 \%(n=47,870)$ of the entire study population, making it difficult to have comparative analysis between countries.

\section{REFERENCES}

1 Zhou Y, Zhang Z, Tian J, Xiong S. Risk factors associated with disease progression in a cohort of patients infected with the 2019 novel coronavirus. Ann Palliat Med. 2020;9(2):428-36.

2 University JH. Coronavirus Resource Center [Internet]. 2020 [cited 2020 Apr 28]. Available from: https://coronavirus.jhu.edu/map.html.

3 Borba MGS, Val FFA, Sampaio VS, Alexandre MAA, Melo GC, Brito M, et al. Chloroquine diphosphate in two different dosages as adjunctive therapy of hospitalized patients with severe respiratory syndrome in the context of coronavirus (SARS-CoV-2) infection: Preliminary safety results of a randomized, double-blinded, phase Ilb clinical trial (CloroCovid-19 Study). Infectious Diseases [Internet].2020. Available from: https://www.medrxiv. org/content/10.1101/2020.04.07.20056424v2.full.pd.

4 Wang L, Duan Y, Zhang W, Liang J, Xu J, Zhang Y, et al. Epidemiologic and Clinical Characteristics of 26 Cases of COVID-19 Arising from Patient-toPatient Transmission in Liaocheng, China. Clin Epidemiol. 2020; 12:387-391.

5 Li X, Xu S, Yu M, Wang K, Tao Y, Zhou Y, et al. Risk factors for severity and mortality in adult COVID-19 inpatients in Wuhan. A Allergy Clin Immunol [Internet]. 2020. Available from: https://doi.org/10.1016/j.jaci.2020.04.006.

6 Shi Y, Yu X, Zhao H, Wang H, Zhao R, Sheng J. Host susceptibility to severe COVID-19 and establishment of a host risk score: findings of 487 cases outside Wuhan. Crit Care [Internet]. 2020;24:108. Available from: https:// doi.org/10.1186/s13054-020-2833-7.

7 Wang D, Hu B, Hu C, Zhu F, Liu X, Zhang | et al. Clinical characteristics of 138 hospitalized patients with 2019 novel coronavirus-infected pneumonia in Wuhan, China. JAMA. 2020; 323(11):1-9.

8 Chen N, Zhou M, Dong X, Qu J, Gong F, Han Y, et al. Epidemiological and clinical characteristics of 99 cases of 2019 novel coronavirus pneumonia in Wuhan, China: a descriptive study. The Lancet. 2020;395(10223), 507-513.

9 Epidemiology Group of the New Coronavirus Pneumonia Emergency Response Mechanism of the Chinese Center for Disease Control and Prevention. Epidemiological characteristics of the new coronavirus pneumonia. Chin J Epidemiol. 2020; 41(2):145-151.

10 Lai CC, Shih TP, Ko WC, Tang HI, Hsueh PR. Severe acute respiratory syndrome coronavirus 2 (SARS-CoV-2) and coronavirus disease-2019 (COVID-19): The epidemic and the challenges. Int J Antimicrob Agents. 2020;55(3):1-9.
Based on the results presented, we advocate that studies on the profile of Covid-19 patients should include the occupation variable. In Brasil, this recommendation is of the utmost importance because it will allow us to know the risk profile and the impact of occupations in the magnitude of the pandemic. Such knowledge may subsidize the development of policies aimed at health workers and guide the process of reopening of companies/trade after this critical stage of the pandemic.

\section{Author's Contribution}

Carlos DFSouza; Aisla GG Santos; Euclides JO Cunha; Tatiana F Oliveira; Saulo HS Aquino; Rodrigo da Rosa Mesquita; Luiz CFS Junior; Fernanda MS Santana; Rafaela C Alcântara; Gabriel M Arnozo; Etvaldo RS Filho participated in the concept development, planning of the study, data collection and analysis, discussion of the results, scientific drafting, as well as in the review and approval of the final version of the paper.

11 Li Q, Guan X, Wu P, Wang X, Zhou L, Tong Y, et al. Early Transmission Dynamics in Wuhan, China, of Novel Coronavirus-Infected Pneumonia. N Engl | Med. 2020; 382(13):1199-1207.

12 An P, Song P, Wang Y, Liu B. Asymptomatic Patients with Novel Coronavirus Disease (COVID-19). Balkan Med I [Internet]. 2020.Available from: http:// www.balkanmedicaljournal.org/uploads/pdf/pdf_BMJ_2206.pdf.

13 Wang X, Liu W, Zhao J, Lu Y, Wang X, Yu C, et al. Clinical characteristics of 80 hospitalized frontline medical workers infected with COVID-19 in Wuhan, China. I Hosp Infect [Internet]. 2020. Available from: https://www. ncbi.nlm.nih.gov/pubmed/32302722.

14 Liu M, He P, Liu HG, Wang XJ, Li FJ, Chen S, et al. Clinical characteristics of 30 medical workers infected with new coronavirus pneumonia. Zhonghua Jie He He Hu Xi Za Zhi [Internet]. 2020;43. Available from: http: //rs.yiigle. com/yufabiao/1181989.htm.

15 Cao J, Tu WJ, Cheng W, Yu L, Liu YK, Hu X, et al. Clinical Features and Short-term Outcomes of 102 Patients with Corona Virus Disease 2019 in Wuhan, China. Clin Infect Dis [Internet].2020. Available from: https:// academic.oup.com/cid/advance-article/doi/10.1093/cid/ciaa243/5814897.

16 Zhan M, Qin Y, Xue X, Zhu S. Death from Covid-19 of 23 Health Care Workers in China. N Engl J Med [Internet]. 2020. Available from: https://www. nejm.org/doi/full/10.1056/NEJMc2005696?url_ver=Z39.88-2003\&rfr_ id=ori:rid:crossref.org\&rfr_dat=cr_pub\%3dpubmed.

17 Chen T, Wu D, Chen H, Yan W, Yang D, Chen G, et al. Clinical characteristics of 113 deceased patients with coronavirus disease 2019: retrospective study. BMJ. 2020;368: 1-12.

18 Zhang J, Wang X, Jia X, Li J, Hu K, Chen G, et al. Risk factors for disease severity, unimprovement, and mortality in COVID-19 patients in Wuhan, China. Clin Microbiol Infect [Internet].2020. Available from: https://www. ncbi.nlm.nih.gov/pubmed/32304745.

19 Chow EJ, Schwartz NG, Tobolowsky FA, Zacks RLT, Huntington-Frazier M, Reddy SC, et al. Symptom Screening at Illness Onset of Health Care PersonnelWith SARS-CoV-2 Infection in King County, Washington. JAMA [Internet].2020. Avaliable from: https://jamanetwork.com/journals/jama/ fullarticle/2764953. doi:10.1001/jama.2020.6637. 
20 Pongpirul WA, Mott JA, Woodring IV, Uyeki TM, MacArthur JR, Vachiraphan A et al. Clinical Characteristics of Patients Hospitalized with Coronavirus Disease, Thailand. Emerging Infectious Diseases [Internet]. 2020; 26(7). Avaliable from: https://wwwnc.cdc.gov/eid/ article/26/7/20-0598_article\#suggestedcitation.

21 Danovaro-Holliday MC, LeBaron CW, Allensworth C, Raymond R, Borden TG, Murray AB, et al. A large rubella outbreak with spread from the workplace to the community. Jama. 2000; 284(21): 2733-2739.
22 Baker MG, Peckham TK, Seixas NS. Estimating the burden of United States workers exposed to infection or disease: a key factor in containing risk of COVID-19 infection. PloS one. 2020; 15(4): 1-8.

23 Costa JMBS, Frias PG. Avaliação da completitude das variáveis da declaração de óbitos de menores de um ano residentes em Pernambuco, 1997-2005. Cienc Saude Colet. 2011; 16(Supl. 1):1267-1274.

24 Burrer SL, Perio MA, Hughes MM, Kuhar DT, Luckhaupt SE, McDaniel C), et al. Characteristics of health care personnel with COVID-19-United States, February 12-April 9. MMWR. 2020; 69(15):1-5. 